\title{
Erratum to: Non-coding RNA: It's Not Junk
}

\author{
C. Richard Boland ${ }^{1}$
}

Published online: 6 September 2017

(C) Springer Science+Business Media, LLC 2017

\section{Erratum to: Dig Dis Sci (2017) 62:1107-1109 \\ DOI 10.1007/s10620-017-4506-1}

The original version of this article unfortunately contained a mistake. The author name should be Boland CR; instead, it was published as C. Richard Boland. This has been corrected with this erratum.

The online version of the original article can be found under doi:10.1007/s10620-017-4506-1.

C. Richard Boland crboland@ucsd.edu

1 GI Division, UCSD School of Medicine, Gilman Drive, San Diego, CA 92093, USA 